Open Access

\title{
Entrepreneurial interest and academic performance in Nigeria: evidence from undergraduate students in the University of Ibadan
}

\author{
Uche A. Osakede*, Akanni O. Lawanson and Deborah A. Sobowale
}

\author{
* Correspondence: \\ royaluchechukwu@gmail.com \\ Department of Economics, \\ University of Ibadan, Ibadan, Nigeria
}

\begin{abstract}
Entrepreneurial interest among the youth population is a panacea for unemployment especially due to high turnout of educated individuals in the labour force. This paper provides findings on the factors that determine entrepreneurship interest among the youth population in Nigeria using the University of Ibadan as a case study. Empirical results on whether engagement in entrepreneurial activities interferes with academic performance; extent of involvement and gender differences are also presented. The logit and multinomial logit models were used to examine the factors that influence entrepreneurship interest and interference with academic performance, respectively. Descriptive statistics and the $T$ test were employed in examining the extent of involvement and whether there is a statistically significant difference across gender. The results showed that subjective norm, perceived behavioural control and family business background significantly predicts students' interest in entrepreneurship. Engagement in entrepreneurial activity has no significant effect on students' academic performance. Findings suggest relatively low entrepreneurial engagement among students with significant differences across gender.
\end{abstract}

Keywords: Entrepreneurial interest academic performance logit, Multinomial logit model $T$ test

\section{Background}

Entrepreneurship has been identified as the best solution to unemployment, underemployment and poverty among the youths, especially in instances where educated individuals cannot find jobs (Brownhilder 2014). It is considered as a key driver of economic growth through increase in manpower contribution to output. The Nigerian economy is highly informal and has low absorption capacity for educated individuals into formal employment. This aggravates unemployment problems especially with huge turnout of educated persons into the labour force. The problem is further worrisome with evidence that most educated graduates in the Nigerian labour force are best suited for white-collar jobs; they do not possess the relevant vocational abilities that enable engagement in entrepreneurship (Olorundare and Kayode 2014). This deficiency in the educational system spurred the Nigerian Universities Commission (NUC)

(c) The Author(s). 2017 Open Access This article is distributed under the terms of the Creative Commons Attribution 4.0 International License (http://creativecommons.org/licenses/by/4.0/), which permits unrestricted use, distribution, and reproduction in any medium, provided you give appropriate credit to the original author(s) and the source, provide a link to the Creative Commons license, and indicate if changes were made. 
to draft a curriculum on entrepreneurship studies for Nigerian universities in 2004 (Ekpoh and Edet 2011). Aside government efforts to encourage entrepreneurship in Nigerian universities, the low-income status of the majority of the Nigerian populace has the tendency to compel student's engagement in entrepreneurial activity as a form of income support. In cases where this situation exists, there are possibly downside effects on academic performance.

In examining entrepreneurial interest, studies have mainly focused on the determinants of entrepreneurial intention with less focus on actual engagement in entrepreneurship (Fitzsimmons and Douglas 2005; Urve et al. 2007; Ismail et al. 2009; Tong et al. 2011; Khan et al. 2011; Adnan et al. 2012; Peng et al. 2012; Kume et al. 2013; Brownhilder 2014; Malebana 2014; Khuong and An 2016; Ayegba and Omale 2016). The emphasis, therefore, is on the inclination of an individual to start an entrepreneurial activity in the future (Per, 1995; Gelderen et al. 2008). Although entrepreneurial intention is the primary step towards the creation of a new venture in the entrepreneurial process, individuals already engaged in entrepreneurship unequivocally have a higher possibility of owning a business venture in future. There is, therefore, a dearth in the literature for studies that provide findings for determinants of entrepreneurial engagement particularly among students and whether it has any effect on academic performance. This study contributes to existing research in the literature by examining the determinants of entrepreneurial engagement among undergraduate students and whether such activity has any effect on academic performance.

The methodology adopted in this study also differs from approaches commonly used in the literature. Studies in the literature among other estimation types generally made use of the ordinary least square (OLS) regression technique for examining factors that affect entrepreneurial intention as a binary response dependent variable. This approach lends itself to the linear probability model (LPM). This study adopts a different method by use of the logit model in examining the determinants of entrepreneurial interest as a binary dependent variable. The logit, probit and LPM models are mainly used for the analysis of binary dependent variables. However, the logit and probit models are preferred over the LPM. This is because they provide probability figures that lie between expected limits of 0 and 1, which sometimes is not achieved, with the LPM (Damodar 2004). The choice of the logit over probit in this study is subjective and based on the assumption that the data set has a logistic distribution. This study hence examined the factors that influence student's engagement in entrepreneurial activity and whether such involvement has any effect on academic performance using the University of Ibadan as a case study. The study also examined the extent of involvement in entrepreneurship across gender in order to add to existing mixed literature findings on gender participation in entrepreneurship.

\section{Theoretical background}

Theoretical explanations of entrepreneurial interest abound in the literature; Becker's (1964) human capital theory, Shapero and Sokol's (1982) entrepreneurial event theory, Bandura's (1986) theory of social learning and Ajzen's (1991) theory of planned behaviour.

The human capital theory, by Becker (1964), mainly assumes that formal education is essential and necessary to improve the productive capacity of a population. It emphasises the role of education in increasing the individual's productive capacity and self- 
efficacy by enhancing their reasoning capability. Entrepreneurial human capital in this light is defined in terms of an individual's entrepreneurial abilities and attitudes. Entrepreneurial abilities capture opportunity recognition, viability screening and creative problem-solving skills, while entrepreneurial attitudes refer to autonomy, risk, work and income of the individual (Douglas and Shepherd 2005).

According to Shapero and Sokol's (1982) theory of entrepreneurial event, the desire to be self-employed depends on the individual's perception of desirability and feasibility in relation to entrepreneurship. An individual first needs to see the act of selfemployment as desirable before the formation of interest and hence engagement. Feasibility relates to an individual's perception of available resources; knowledge, financial support and skill. On the other hand, desirability relates to the individual's attitude, values and feelings, which are shaped by the social environment consisting of family, friends and colleagues.

Bandura's (1986) social learning theory, also referred to as social cognitive theory, identifies human behaviour as interaction of personal factors, behavioural factors and the environment. The focus of personal factors is on having low or high self-efficacy. Behavioural factors refer to the reaction the individual receives after performing a particular behaviour, which could be positive or negative. Environmental factors capture the influence from the environment in carrying out an activity.

Other theories such as Ajzen's (1991) theory of planned behaviour (TPB) predict that intent is dependent on three factors, which are attitude, subjective norm and perceived behavioural control. These factors give rise to the intention and hence engagement in a particular behaviour. Attitude is defined as the degree to which an individual has desirable or undesirable appraisal of the behaviour in concern. It measures the value the individual places on a behaviour type. Subjective norm, on the other hand, refers to social pressure or influence from one's parents, peers and other respected relatives to engage or not to participate in an act or behaviour. Perceived behavioural control captures the individual's perception of his or her ability to perform the behaviour and if there are resources to do so. Most studies have modelled entrepreneurial intention in line with the TPB. This is due to the fact that the TPB is most recent among behavioural theories in the literature and encompasses variables in other theories of entrepreneurial intention.

There are mixed findings on factors that influence entrepreneurial intention. In most cases, not all TPB variables significantly determine the intention to own a business. For instance, in examining responses of undergraduate students to the question of entrepreneurial interest, Adnan et al. (2012) showed that attitude and perceived behavioural control are major determinants of entrepreneurial intention with significant positive effect. The implication, therefore, is that subjective norm has insignificant impact on entrepreneurial intention among university undergraduate students. Study findings were provided with simple regression analysis between entrepreneurial intention and TPB variables.

In a related study, Tong et al. (2011) using multiple regression analysis, showed that entrepreneurial intention is predicted by the need for achievement, family business background and subjective norm. The result suggests that students will choose to become entrepreneurs if there is a need for achievement, when they come from a family that engages in business and if there is support from close individuals such as family members and friends. 
Another study by Fitzsimmons and Douglas (2005) examined the relationship between entrepreneurial attitudes, abilities and entrepreneurial intentions in India, China, Thailand and Australia. Using the OLS technique, entrepreneurial attitudes were found to be significant in explaining career decisions of individuals. Ownership attitude was shown to have the most influence on entrepreneurial intentions. Generally, individual's desire for more income, independence and less risk in making a career decision determined interest in entrepreneurship.

Peng et al. (2012) provides findings for entrepreneurial intention among university students in China with the use of the chi-square tests. It was showed that subjective norm, entrepreneurial attitude and entrepreneurial self-efficacy had positive influence on entrepreneurial intention while entrepreneurial resistance caused by lack of funds, time, family support, business skills and entrepreneurship education negatively affect students' entrepreneurial intention.

Using descriptive statistics, Kume et al. (2013) provide evidence of positive effects of subjective norm on entrepreneurial interest among undergraduate students in Albania. Students whose parents had entrepreneurial experience were more in the distribution of respondents who indicated interest in starting their own business after graduation. This supports arguments that prior exposure to entrepreneurship either directly or indirectly through the family background influences the individual's attitudes regarding entrepreneurship.

One study by Khuong and An (2016) showed that prior entrepreneurial experience, external environment such as availability of loan and access to target markets as well as perceived feasibility, positively influenced students desire to engage in entrepreneurship in Vietnam. On the other hand, personal traits, the need for autonomy and achievement surprisingly deter interest in entrepreneurial engagement.

In a related study, Nguyen (2017) provides findings for the determinants of entrepreneurial intention among international business students in Vietnam. With the use of an exploratory factor analysis and multiple regressions, it was showed that attitude towards entrepreneurship and perceived behavioural control are the TPB variables that had significant effect on students' interest in entrepreneurship. This suggests that subjective norm does not have any influence on the intention to be an entrepreneur.

In Nigeria, Ayegba and Omale (2016) provide findings on factors that influence entrepreneurial development among small and medium scale business owners. Using chisquare statistics to examine responses on determinants of entrepreneurial development, it was showed that entrepreneurship development in Nigeria depends on environmental factors such as power supply, access to credit facility as well as modern technology.

Some studies have grouped the factors that influence entrepreneurial interest into categories of push and pull factors ${ }^{1}$. Brownhilder (2014), for instance, showed that in Cameroon, push factors such as unemployment, poverty and job security were predominant determinates of students' engagement in various forms of entrepreneurship. In a related study, Malebana (2014) showed that students were more pulled rather than pushed into entrepreneurship. In other words, students were interested in entrepreneurship mainly as a result of positive factors such as the opportunity to make use of creative talents, independence and prospects for higher earnings than through negative factors such as high prevalence of unemployment. Studies have further showed that 
entrepreneurship considerations are not actualised as a desired career choice basically due to lack of funding, business skills, existence of many competitors and fear of failure (Urve et al. 2007, Brownhilder 2014).

In terms of gender, findings for participation in entrepreneurship is non-uniform. There is no consensus on whether males have higher tendency to engage in entrepreneurial activities than females and vice versa (Ismail et al. 2009; Khan et al. 2011; Camillus and Anthony, 2014). There are, however, evidence that the student's course of study influences the extent of entrepreneurial participation. It is showed that science students have the highest risk taking scores in entrepreneurship, followed by business and arts students. Student's exposure to entrepreneurial courses also significantly influence entrepreneurial intention (Ismail et al. 2009; Khan et al. 2011).

In examining entrepreneurship, there are scarcity of findings on entrepreneurial engagement and academic performance. It is evident that studies have commonly focused on the determinants of entrepreneurial intention among students with less attention on factors that influence engagement in entrepreneurship and whether there are interferences with academic performance. The effect of student engagement in entrepreneurship on academic performance can be deduced from the predictions of the theory of time use. Becker (1965) provides a framework for trade-off of time allocation with constraints of time endowment. Becker's (1965) theory of time use assumes that the household has a particular time endowment per time, which is spent on the production of goods produced at home. Although this theory relates to time use by household, it also explains constraints to time allocation and opportunity cost associated with spending time allocated to a particular activity for other purposes. Some studies have adopted the theory of time use as a framework for modelling work hours lost due to illness and loss in work time of females in cases of working husbands providing reservation income (Schultz and Tansel 1997; Buchmueller and Valletta 1999, Bridges and Lawson 2008; Machio 2012; Abamba 2016). Where the student engages in business activity, time spent on study would somewhat be reduced. This is because of possible trade-off of some amount of study time for business activity given fixed time allocation per day. This time trade-off arguably poses unfavourable effect on academic performance. The possible reduction in time allocation to academic purpose for other activities such as entrepreneurial engagement is yet to be amply explored in the literature. In the United States, it was showed that time spent working does not affect the academic performance of college students. This finding is contrary to theoretical underpinnings of the theory of time use and popular belief of constraints in study time for working students (Nonis and Hudson 2006). This study extends literature findings in this regard using study sample from a developing economy like Nigeria.

More so, empirical analysis of factors that influence entrepreneurship mainly considers entrepreneurial intention as a binary outcome dependent variable. Techniques adopted commonly include use of descriptive statistics, chi-square, correlation analysis, test of mean difference, simple and multiple regressions using the OLS technique. Among the techniques adopted in the literature, the OLS apparently provides better presentation of findings because it gives results for statistical significance, magnitude and direction of effect. However, the use of OLS in analysing binary response dependent variables does not guarantee that the probability of an event occurring will yield results that lie between zero and one. The use of the logit and probit models 
solves the problem of OLS estimation for binary dependent variables. The logit and probit models provide some assurance that the estimated probabilities will lie between the logical limits of zero and one and also gives results for statistical significance, magnitude and direction of effect. Estimation techniques for the logit and probit models usually follow the maximum likelihood estimation. Choice of the logit over the probit model and vice versa is subjective and hinge on the assumed distribution of the data (Damodar 2004). In cases of multiple outcome variables, the use of the logit and probit models is extended to a multinomial logit or probit analysis (Damodar 2004).

Overall studies do not generally have consensus findings on the factors that influence entrepreneurial intention. Effects on academic performance also remains a grey area with no uniformity of results. This study contributes to research findings on entrepreneurial intention using data from Nigeria to explore the factors that influence entrepreneurial interest and the effect it has on the students' academic performance.

\section{Methods}

The study sample was extracted from full-time undergraduate students in the University of Ibadan, south-western part of Nigeria. The university was founded in 1948 before national independence as the University College Ibadan and later became the University of Ibadan in 1962. The total undergraduate population during the period of this study, 2014/2015 session, was 12,894 with male and female distribution of 7627 and 5267, respectively (UI, Pocket statistics, 2015).

A minimum sample size $(n)=238$ (rounded to 250 ) was obtained using the formula $n=\frac{Z^{2} \times P \times q}{d^{2}}$ where the population proportion ${ }^{2}, P$, used for the study is assumed to be $0.1,0.1, q=1-p, z=1.645$, (at 90\% confidence interval) and margin error $(d)$ of 0.032 (Cochran 1977; Farris 2011). A structured pretested questionnaire was used for data collection. The questionnaire was pretested on 25 randomly selected undergraduate students. The questionnaire assessed the social economic characteristics of respondents, entrepreneurial engagement and academic performance. A total of 250 pretested copies of questionnaire were administered randomly. Assessment of entrepreneurial engagement was based on the close-ended question format. Respondents were asked to state whether they were currently engaged in a business. They were also asked to state whether they receive encouragement from family members and friends to set up their own business. Questions on entrepreneurial engagement also required respondents to state whether they desire to be their own boss in future, and if there are difficulties in combining business activities with academics. To obtain information on academic performance, respondents were asked to state cumulative grade point average. Other information obtained required respondents to state average monthly income, age, gender, income source, parent's occupation and ethnic group. Information from field survey was coded using Statistical Package for Social Sciences (SPSS) version 20.0, and estimations were carried out using STATA 11.

The analytical model adopted in this study borrows from the TPB by Ajzen (1991). Given that the outcome of entrepreneurial intention is engagement in entrepreneurship, it is arguable that similar theoretical postulations apply to both concepts. In line with the theory's supposition, the factors that influence the students' behaviour in relation to entrepreneurship rest on three variables: attitude, subjective norm and 
perceived behavioural control. The functional form of the entrepreneurial interest of a student is hence specified as:

$$
\mathrm{E}_{i}=\mathrm{E}_{i}\left(\mathrm{ATT}_{i}, \mathrm{SN}_{i}, \mathrm{PBC}_{i}\right)
$$

Where $\mathrm{E}_{i}$ captures the entrepreneurial interest of a student $i$; $\mathrm{ATT}_{i}$ represents the student's attitude; $\mathrm{SN}_{i}$ connotes subjective norm and $\mathrm{PBC}_{i}$ is perceived behavioural control. $\mathrm{ATT}_{i}$ is further defined by the desire to be one's own boss, $\mathrm{SN}_{i}$ is captured by encouragement from family members, friends and relatives to start up a business and $\mathrm{PBC}_{i}$ is measured by the ability to combine business and academics (Gelderen et al. 2008).

We control for other variables that influence entrepreneurial engagement in the model. Following Khan et al. (2011), other covariates such as the gender of the student $\left(\mathrm{GEN}_{i}\right)$, age $\left(\mathrm{AGE}_{i}\right)$, ethnicity $\left(\mathrm{ETH}_{i}\right)$, family business background $\left(\mathrm{FBB}_{i}\right)$ and income $\left(\mathrm{INC}_{i}\right)$ are included in the model. Equation 1 is hence respecified as:

$$
\mathrm{E}_{i}=\mathrm{E}_{i}\left(\mathrm{ATT}_{i}, \mathrm{SN}_{i}, \mathrm{PBC}_{i}, \mathrm{GEN}_{i}, \mathrm{AGE}_{i}, \mathrm{ETH}_{i}, \mathrm{FBB}_{i}, \mathrm{INC}_{i}\right)
$$

Gender as a predictor variable is meant to determine whether males are more likely engaged in entrepreneurship than females and vice versa. This would provide finding on possible future trend of entrepreneurship across gender in the county. The inclusion of age is meant to provide findings for the age group of individuals that are most likely engaged in entrepreneurship. It is expected that older students are better exposed to entrepreneurial skills and more able to manage entrepreneurial engagement alongside academic work. Ethnicity is considered as an explanatory variable because of the cultural diversity in Nigeria. The University of Ibadan is located in the south-west part of the country where majority of residents speak the Yoruba dialect. It, however, admits students from different ethnic groups in the country. It is expected that the students who are from the Yoruba tribe would engage more in entrepreneurship due to familiarity with the environment. Family business background is also considered as an explanatory variable in the model to determine whether transfer of experience from family members influences the student's engagement in entrepreneurship. Income is also considered as a predictor variable to determine whether participation in entrepreneurship is in any way explained by the monthly income of the student or cash allowance received.

For the purpose of estimation, the equation for entrepreneurial interest in the study is presented as:

$$
\mathrm{E}_{i}=\beta_{0}+\beta_{1} \mathrm{ATT}_{i}+\beta_{2} \mathrm{SN}_{i}+\beta_{3} \mathrm{PBC}_{i}+\beta_{4} \mathrm{GEN}_{i}+\beta_{5} \mathrm{AGE}_{i}+\beta_{6} \mathrm{ETH}_{i}+\beta_{7} \mathrm{FBB}_{i}+\beta_{8} \mathrm{INC}_{i}
$$

Where $\mathrm{E}_{i}$ is measured as a binary variable, with the value of 1 , assigned to those who are already engaged in entrepreneurship and 0 otherwise.

$\mathrm{ATT}_{i}, \mathrm{SN}_{i}$ and $\mathrm{PBC}_{i}$ are also measured as binary variables. $\mathrm{ATT}_{i}$ is assigned 1 for positive $^{3}$ response to the question of the desire to become one's own boss and 0 otherwise. $\mathrm{SN}_{i}$ is similarly measured as 1 for positive response to receiving encouragement from family member's friends and relatives to start a business and 0 otherwise. And $\mathrm{PBC}_{i}$ is considered as 1 for subjective judgement of student's ability to combine business and academics and 0 otherwise. Other covariates are also measured in categorical forms. GEN for instance, is measured as a categorical variable assuming the value of 1 for male students and 0 for females. $\mathrm{AGE}_{i}$ is grouped into four categories: between 16 and 20 years, 
21 and 25 years, 26 and 30 years and above 30 years. Age grouping was bounded below from 16 years because the University of Ibadan disallows admission of students below this age from entry into the regular undergraduate program. $\mathrm{ETH}_{i}$ is also measured in four categories: Hausa, Igbo, Yoruba and other ethnic groups. Hausa, Yoruba and Igbo are the major ethnic groupings in Nigeria. Others are considered as minority tribes. $\mathrm{FBB}_{i}$ is measured as a binary variable with a value of 1 assigned to students whose parents are self-employed and 0 otherwise. This is to capture parental background of the student in terms of entrepreneurship. Parents who are in self-employment ${ }^{4}$ work-type are unanimously entrepreneurs. $\mathrm{INC}_{i}$ is measured in groups of less than $\$ 10,000$, between $\$ 10$, 000 and $\$ 20,000, \$ 21,000$ and $\$ 30,000$ as well as $\$ 31,000$ and above.

Given binary outcome variables in Eq. 3, the model for entrepreneurial interest is examined using the logit model. It is assumed that the data follows a logistic distribution (Damodar 2004).

Where students' involvement in entrepreneurial activities influences academic performance, Eq. 4 is specified using entrepreneurial interest as an independent variable, in order to explain its effect on academic performance. Following the assumption of the theory of time use, time spent on entrepreneurial activity is a constraint to the time endowment of the student and hence influences academic performance. In this case, it is assumed that given the students interest in academic pursuit, time spent studying should assumable constitutes a major part of time use so that entrepreneurial time interferes with study time and hence explains academic performance. We thus include the student's response to engagement in entrepreneurship as an independent variable to capture time spent on entrepreneurial engagement. Following Nonis and Hudson (2006), we controlled for social economic factors such as the student's age $\left(\mathrm{AGE}_{i}\right)$ gender $\left(\mathrm{GEN}_{i}\right)$ and income $\left(\mathrm{INC}_{i}\right)$ in the model of academic performance. The functional form of the model for academic performance is hence specified as:

$$
\mathrm{ACP}_{i}=\mathrm{ACP}_{i}\left(\mathrm{E}_{i}, \mathrm{AGE}_{i}, \mathrm{GEN}_{i}, \mathrm{INC}_{i_{i}}\right)
$$

Where $\mathrm{ACP}_{i}$ indicates academic performance of a student $i . \mathrm{E}_{i}, \mathrm{AGE}_{i}, \mathrm{GEN}_{i}, \mathrm{INC}_{i_{i}}$ are as earlier defined. We include age to determine whether it has any influence on better management of time and hence academic performance. It is expected that older students would have better time management ability and hence do better in their studies. The inclusion of gender is meant to capture any possibility of differences across males and females in academic performance. It is difficult to predict academic performance across gender. The expected effect of gender on academic performance is hence ambiguous. The student's income inevitably influences the baskets of goods that can be purchased including study items which invariably affects academic performance. We thus expect that students receiving higher income should have better grades.

For the purpose of estimation, Eq. 4 is specified as:

$$
\mathrm{ACP}_{i}=\beta_{0}+\beta_{1} \mathrm{E}_{i}+\beta_{2} \mathrm{AGE}_{i}+B_{3} \mathrm{GEN}_{i}+\beta_{4} \mathrm{INC}_{i}
$$

Where $\mathrm{ACP}_{i}$ is measured in three outcomes which are first class $\left(\mathrm{ACP}_{i}=1\right)$, second class $\left(\mathrm{ACP}_{i}=2\right)$ and third class $\left(\mathrm{ACP}_{i}=3\right)$. The outcomes are captured using the cumulative grade point average (CGPA), which gives the class of degree of each student. The definition and measurement of $\mathrm{E}_{i}, \mathrm{AGE}_{i} \mathrm{GEN}_{i}$ and $\mathrm{INC}_{i}$ are the same as earlier stated. The specification of Eq. 5 in multiple outcome dependent variables for same sets of exogenous 
variables lends itself to the use of the multinomial logit model and the maximum likelihood estimation technique (Damodar 2004). The maximum likelihood technique provides estimates for the probability of an outcome for each of the response variable.

We further examined the extent of involvement in entrepreneurship using descriptive statistics and test of mean difference across gender with the use of the $\mathrm{T}$ test.

\section{Results and Discussions}

The results for summary statistics of the variables used in the study and factors influencing students' interest in entrepreneurship are shown in Tables 1 and 2, respectively. The effect of entrepreneurial activities on academic performance and the extent of students' engagement in entrepreneurship across gender are shown in Tables 3 and 4. Findings on whether there are significant differences on entrepreneurial involvement across gender are shown in Table 5. Variables used in the study are

Table 1 Summary statistics of variables

\begin{tabular}{|c|c|c|c|}
\hline Variables & Mean & Minimum & Maximum \\
\hline Engaged in entrepreneurship & .32 & 0 & 1 \\
\hline Not engaged in entrepreneurship & .68 & 0 & 1 \\
\hline Attitude: desire to be one's own boss & .98 & 0 & 1 \\
\hline Attitude: no desire to be one's own boss & .02 & 0 & 1 \\
\hline Subjective norm: favourable family support & .812 & 0 & 1 \\
\hline Subjective norm: unfavourable family support & .188 & 0 & 1 \\
\hline Subjective norm: friends support & .836 & 0 & 1 \\
\hline Subjective norm: no support from friends & .164 & 0 & 1 \\
\hline $\begin{array}{l}\text { Perceived behavioural control: difficult to combine academics with } \\
\text { entrepreneurship }\end{array}$ & .532 & 0 & 1 \\
\hline $\begin{array}{l}\text { Perceived behavioural control: not difficult to combine academics with } \\
\text { entrepreneurship }\end{array}$ & .468 & 0 & 1 \\
\hline Male & .632 & 0 & 1 \\
\hline Female & .368 & 0 & 1 \\
\hline Age in years (16-20) & .432 & 0 & 1 \\
\hline Age in years $(21-25)$ & .524 & 0 & 1 \\
\hline Age in years $(26-30)$ & .036 & 0 & 1 \\
\hline Age in years (31 and above) & .008 & 0 & 1 \\
\hline Hausa & .004 & 0 & 1 \\
\hline Igbo & .136 & 0 & 1 \\
\hline Yoruba & .756 & 0 & 1 \\
\hline Others & .104 & 0 & 1 \\
\hline Parents: self-employed & .412 & 0 & 1 \\
\hline Parents: salary worker & .40 & 0 & 1 \\
\hline Parents: unemployed & .128 & 0 & 1 \\
\hline Parents: retired & .06 & 0 & 1 \\
\hline 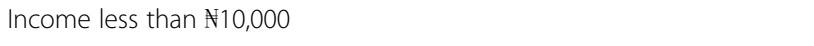 & .26 & 0 & 1 \\
\hline Income $\mathrm{N10,000}$ to $\mathrm{N20,000}$ & .532 & 0 & 1 \\
\hline Income $\mathrm{N20,000}$ to $\mathrm{N30,000}$ & .156 & 0 & 1 \\
\hline Income above $\$ 30,000$ & .052 & 0 & 1 \\
\hline
\end{tabular}

Source: authors' computation 
Table 2 Logit estimates of determinants of entrepreneurial interest (reference category is no interest in entrepreneurship)

\begin{tabular}{|c|c|}
\hline Variable & Estimates \\
\hline \multicolumn{2}{|c|}{ Subjective norm: not encouraged by family or friends is the reference category } \\
\hline Encouraged by family & $0.99^{\mathrm{b}}(0.018)$ \\
\hline Encouraged by friends & $0.60(0.136)$ \\
\hline \multicolumn{2}{|c|}{ Perceived behavioural control: no difficulty in combining business and academics is the reference category } \\
\hline Difficult & $-0.63^{\mathrm{b}}(0.021)$ \\
\hline \multicolumn{2}{|c|}{ Gender: female is the reference category } \\
\hline Male & $0.03(0.902)$ \\
\hline \multicolumn{2}{|c|}{ Age in years: above 30 years is the reference category } \\
\hline $16-20$ & $-0.99^{c}(0.001)$ \\
\hline $21-25$ & $0.92^{\mathrm{C}}(0.001)$ \\
\hline $26-30$ & $0.06(0.930)$ \\
\hline \multicolumn{2}{|c|}{ Ethnic group: Hausa is the reference category } \\
\hline Igbo & $-0.68(0.130)$ \\
\hline Yoruba & $0.59^{\mathrm{a}}(0.084)$ \\
\hline Others & $-0.5(0.307)$ \\
\hline \multicolumn{2}{|c|}{ Parents' occupation: retired is the reference category } \\
\hline Self-employed & $0.91^{\mathrm{C}}(0.001)$ \\
\hline Salary worker & $0.80^{\mathrm{C}}(0.006)$ \\
\hline Unemployed & $-0.80^{\mathrm{a}}(0.092)$ \\
\hline \multicolumn{2}{|c|}{ Income: above $\mathrm{A} 31,000$ is the reference category } \\
\hline Less than $\mathrm{N10,000}$ & $-0.27(0.388)$ \\
\hline $\mathrm{A} 10,000-\mathrm{N} 20,000$ & $0.48^{\mathrm{a}}(0.076)$ \\
\hline $\mathrm{N} 21,000-\mathrm{N30,000}$ & $0.60^{\mathrm{a}}(0.094)$ \\
\hline Constant & $14.55(0.982)$ \\
\hline \multicolumn{2}{|l|}{ Diagnostics } \\
\hline \multicolumn{2}{|c|}{ LR chi2 $(16)=49.84$ prob. $>$ chi2 $=0.0000$} \\
\hline \multicolumn{2}{|l|}{ Pseudo $R^{2}=0.1610$} \\
\hline Observation 245 & \\
\hline
\end{tabular}

Source: authors' computation

Marginal effects of coefficients are reported with $z$-values in bracket

Superscript letters indicate statistical significance at 1, 5 and $10 \%$, respectively

basically categorical with mean values from summary statistics showing the percentage composition of each variable.

\section{Source: authors' computation}

From Table 1, only about $32 \%$ of the study samples were engaged in entrepreneurship. More than half of the study sample (68\%) were not in any form of entrepreneurial activity. However, most of the respondents (98\%) showed favourable attitude towards entrepreneurship. This is possible because most of the respondents receive encouragement from family and friends in relation to setting up their own business. Approximately $81 \%$ of the respondents get support from family members and about $84 \%$ receive encouragement from friends. The distribution of respondents in terms of their perceived behavioural control showed that slightly above half of the sample (53\%) find 
Table 3 Multinomial logit estimate for effect of entrepreneurial activities on academic performance (reference category is second class)

\begin{tabular}{lcc}
\hline Variables & First class & Third class \\
\hline Entrepreneurial activity (not presently in a business is the reference category) & $-0.42(0.357)$ & $-1.50(0.193)$ \\
Presently engaged in a business & $15.69(0.997)$ & $15.35(0.998)$ \\
Age in years (above 30 years is the reference category) & $15.05(0.997)$ & $14.32(0.998)$ \\
$16-20$ & $-0.54(1.000)$ & $-0.80(1.000)$ \\
$21-25$ & & $0.24(0.744)$ \\
$26-30$ & $0.31(0.441)$ & \\
Gender (female is the reference category) & $-1.64^{\mathrm{a}}(0.036)$ & $-1.92(0.161)$ \\
Male & $-1.87^{\mathrm{a}}(0.012)$ & $-2.33(0.081)$ \\
Income (above $\mathrm{N31,000}$ is the reference category) & $-1.91^{\mathrm{a}}(0.026)$ & $-16.97(0.991)$ \\
Less than $\mathrm{N10,000}$ & $-15.50(0.997)$ & $-15.63(0.998)$ \\
N10,000 to $\mathrm{N20,000}$ & & \\
N21,000 to $\mathrm{N} 30,000$ & & \\
Constant &
\end{tabular}

Source: authors' Computation

Marginal effects of coefficients are reported with $z$-values in bracket

Superscript letter indicates statistical significance at $5 \%$

it difficult to combine entrepreneurship with academics. This can be a reason for the relatively low proportion of students engaged in entrepreneurial activity while in school. Gender distribution showed that there are more males (63\%) than females (37\%) in the sample. These statistics follow a similar pattern of gender distribution of students in the University of Ibadan. A relatively larger proportion of the respondents were between the age group of 16 and 20 years (43\%) as well as 21 and 25 years (52\%). Students between the age bracket of 26 and 30 years were about $4 \%$ and those above 30 years comprised a very small amount (approximately 1\%). Majority of the respondents were from the Yoruba ethnic group (75\%). This could be due to the location of the university in the western part of the country, an indigenous homeland of the Yorubas. Students who are from Hausa ethnic group had the lowest proportion (less than 1\%). Parent's information showed that parental employment type is mainly self- and wage employment. About $41 \%$ of the sample population had parents who were self-employed and $40 \%$ of parents were in wage employment. Approximately $13 \%$ of parents were unemployed and $1 \%$ were retirees. Most students received pocket allowance or income between $\$ 10,000$ and $\$ 20,000$ (53\%). Students who receive above 30,000 comprised only $1 \%$.

The logit regression result shows that variables with significant effect on entrepreneurial interest include subjective norm: support from family members, perceived behavioural control, age, ethnic group, family business background and income. Similar

Table 4 Result for involvement in business across gender

\begin{tabular}{llll}
\hline Currently engaged in business & Male & Female & Total \\
\hline No & $107(62.9 \%)$ & $63(37.1 \%)$ & $170(68 \%)$ \\
Yes & $51(63.7 \%)$ & $29(36.3 \%)$ & $80(32 \%)$ \\
Total & $158(63 \%)$ & $92(37 \%)$ & 250 \\
\hline
\end{tabular}

Source: authors' Computation 
Table $5 \mathrm{~T}$ test result for mean difference of involvement in entrepreneurship across gender

\begin{tabular}{llll}
\hline Variable & Observation & Mean & Standard error \\
\hline Male & 80 & .6375 & .0540855 \\
Female & 80 & .3625 & .0540855 \\
Difference & 80 & .275 & .1081709 \\
mean(diff) $=$ mean(male-female) $t=2.5423$ & & & \\
\hline
\end{tabular}

Source: authors' Computation

results were found in Peng et al. (2012) and Tong et al. (2011). The result also showed that entrepreneurial interest among students was not gender driven, as there was no significant difference between male and female interest in entrepreneurship. Ismail et al. (2009) found similar results.

The results showed that students who receive encouragement from family members have a higher likelihood of engagement in entrepreneurship relative to those who do not receive family support. Students who perceive that they would not be able to combine entrepreneurial activity with academic work show negative tendency of engagement in entrepreneurship. Result for age effects on entrepreneurship revealed that interest in entrepreneurship rises with age, especially for students between the age bracket of 21 and 25 years. The result also suggests that students whose parents are currently employed are more likely to engage in entrepreneurship. This is particularly for those with parents in self-employment. This suggests that family business background significantly influences students' entrepreneurial interest. The result conforms to findings by Kume et al. (2013), Camillus and Anthony (2014).

Results for ethnic group showed that being a student from the Yoruba ethnic group improves the chance of engagement in entrepreneurship relative to the student from the Hausa ethnic group. This could be because of leverage on tribal influence and acquaintance with the environment. The result also suggests an increase in the likelihood of entrepreneurial engagement with increase in income or pocket allowance.

The result showed that engagement in business had no statistically significant effect on students' academic performance. The result showed that the age of students and gender do not determine academic performance. However, the results for income showed that students' monthly income significantly influences academic performance for students with a first class relative to those with a second-class CGPA. The result suggests a rise in the likelihood of a student to have a first class with a rise in income. Students who received less than $\$ 10,000$ as income are the most unlikely to have a first-class degree compared to those who receive above $\$ 30.000$. The monthly income of students had no significant effect on academic performance of students with a third-class CGPA. In other words, being a student with a third class is not attributable to income, age or gender.

In terms of student's involvement in entrepreneurship across gender, it is showed that more male students responded positively to entrepreneurial engagement compared to females. The results for gender distribution of students engaged in entrepreneurship are shown in Table 4.

From a total of 250 respondents, 80 (32\%) were engaged in business. Gender distribution of students engaged in entrepreneurship showed that 51(approximately 64\%) were males and 29 (about 36\%) females. A relatively larger proportion of students (68\%) were not engaged in business as at the time of the study. 
Test of significance of involvement in entrepreneurship across gender revealed existence of statistically significant differences.

Given mean estimate of about $64 \%$ of male involvement in entrepreneurship and approximately $36 \%$ of female engagement in entrepreneurship, the $t$-statistics of 2.5423 rejects the null hypothesis at $1 \%$ that the mean difference is the same. This shows that there is a statistically significant difference in the gender involvement in entrepreneurship. The result suggests that male students are more engaged in entrepreneurship than females.

\section{Conclusions}

This study was set out to identify factors that influence students' interest in entrepreneurship, the effect of entrepreneurial activities on students' academic performance and gender differences in entrepreneurial involvement. The result suggests that subjective norm and perceived behavioural control significantly influences students' interest in entrepreneurship. Findings also showed that students' engagement in business activities has no significant effect on academic performance. The results also indicate that a large proportion of students do not engage in entrepreneurial activities. However, student's interest in entrepreneurship is commonly seen among males than female students.

Government actions to promote entrepreneurship in tertiary institutions should be further intensified in order to achieve required aim of reducing unemployment for the teeming Nigerian graduate population. Focus areas in curricular course work for entrepreneurship in Nigerian universities should consider modules that influence the student's attitude, subjective norm and perceived behavioural control.

One shortcoming of this study relates with extraction of findings only for university undergraduate students. The tertiary educational system in Nigeria covers other forms of education such as the polytechnic and colleges of education. The problems of unemployment that characterise the Nigerian work force also apply to graduates from such institutes. Future studies can focus on sample extraction from these institutes to enrich literature findings.

\section{Endnotes}

${ }^{1}$ Push factors are negative features that force an individual to engage in a particular activity. While pull factors refers to positive influences that lead to a particular action.

${ }^{2}$ We could not make use of the conventional population proportion of $5 \%$ where there are no references of $P$ in previous studies. The choice of $1 \%$ was chosen basically due to challenges with survey cost (Farris 2011).

${ }^{3}$ Positive attitude was omitted during the analysis because it perfectly predicts failure in the study result.

${ }^{4}$ Where both parents or ward are economically empowered, we considered the occupation of the parent that provides a larger share of the student's income. This is because of the possible psychological effect such provision has on the student.

\footnotetext{
Abbreviations

LPM: Linear probability model; NUC: Nigerian Universities Commission; OLS: Ordinary least square regression;

TPB: Theory of planned behaviour
} 
Funding

Not applicable.

\section{Availability of data and materials}

See additional supporting files.

\section{Authors' contributions}

All authors have contributed substantially to the development of the manuscript. All authors read and approved the final manuscript.

\section{Ethics approval and consent to participate}

Not applicable.

\section{Consent for publication}

Not applicable.

\section{Competing interests}

None of the authors of this paper have financial or non-financial competing interests in the manuscript.

\section{Publisher's Note}

Springer Nature remains neutral with regard to jurisdictional claims in published maps and institutional affiliations.

Received: 19 May 2017 Accepted: 8 September 2017

Published online: 27 September 2017

\section{References}

Abamba U. (2016). Effect of Malaria Ailment on Labour Employment Probability and Cost Implications in Nigeria. Unpublished PhD thesis, Department of Economics, University of Ibadan, Nigeria.

Adnan I., Yahya, M. and Husam K., (2012) Readiness of the University Students towards Entrepreneurship in Saudi private university: An Exploratory Study. European Scientific Journal, 8(15). https://www.researchgate.net/publication/ 215912152_Readiness_of_the_students_towards_Entrepreneurship_A_case_of_Saudi_Private_University. Accessed $6^{\text {th }}$ May 2016

Ajzen, I. (1991). The theory of planned behavior. Organizational Behavior and Human Decision Processes, 50, 179-211. Ayegba, O. and Omale, S. A., (2016) A study on factors affecting entrepreneurial development in Nigeria. European Journal of Business and Management. Vol. 8 (12)

Bandura, A. (1986). Social foundations of thought and action: a social cognitive theory. Englewood Cliffs, NJ: Prentice-Hall. Becker, G. S. (1964). Human capital. New York: The National Bureau of Economic Research.

Becker, G. S. (1965). A theory of time allocation. The Economic Journal, 75(229), 493-519.

Bridges, S., and Lawson, D. (2008). Health and labour market participation in Uganda. World Institute in Development Economies, Research Discussion Papers No 200807.

Brownhilder N. N. (2014). An assessment of entrepreneurial intention among university students in Cameroon. Mediterranean Journal of Social Sciences, 5(20), 542-55.

Buchmueller, T. C., \& Valletta, R. G. (1999). The effect of health insurance on married female labour supply. The Journal of Human Resources, 34(1), 42-70.

Camillus, A. W., \& Anthony, Z. K. S. (2014). Factors influencing polytechnic students' decision to graduate as entrepreneurs. Journal of Global Entrepreneurship Research, 4, 2. https://doi.org/10.1186/2251-7316-2-2.

Cochran, W. G. (1977). Sampling technique (Third ed.). New York: John Wiley and Sons.

Damodar N. G. Economics-basic econometrics (2004). McGraw-Hill, London. https://docs.google.com/file/d/ OB61KSjKBWIfscmdkSVF6VF90NjA/edit.

Douglas, E.J. and Shepherd, D.A. (2005). Entrepreneurial human capital and self-employment decision. Paper presented at the Entrepreneurial Research Exchange, Swinburne University, Melsbourne, Australia.

Ekpoh, U. I., \& Edet, A. O. (2011). Entrepreneurship education and career intentions of tertiary education students in Akwa Ibom and Cross River States, Nigeria. International Education Studies, 4(1), 172.

Farris Y.S. (2011) Estimating appropriate sample size for research on malaria data: a case study of Afigya-Sekyere district. A thesis submitted to the department of mathematics, Kwame Knrumah University of Science and Technology.

Fitzsimmons, J.R., Douglas, E.J. (2005), Entrepreneurial attitudes and entrepreneurial intentions: a cross-cultural study of potential entrepreneurs in India, China, Thailand and Australia, Babson-Kauffman Entrepreneurial Research Conference, Wellesley, MA. June. https://eprints.qut.edu.au/6486/1/6486.pdf. Accessed 12 ${ }^{\text {th }}$ May 2016.

Gelderen, M. V., Brand, M., Praag, M. V., Bodewes, W., Poutsma, E., \& Gils, A. V. (2008). Explaining entrepreneurial intentions by means of the theory of planned behaviour. Career Development International, 13(6), 538-555.

Ismail, M., Khalid, S. A., Othman, M., Jusoff, H. K., Kassim, K. M., \& Zain, R. S. (2009). Entrepreneurial intention among Malaysian undergraduates. International Journal of Business and Management, 4(10), 54-58.

Khan, M. M., Ahmed, I., Nawaz, M. M., \& Ramzan, M. (2011). Impact of personality traits on entrepreneurial intentions of university students. Interdisciplinary Journal of Research in Business, 1(4), 51-57.

Khuong, M. N., \& An, N. H. (2016). The factors affecting entrepreneurial intention of the students of Vietnam National University - a mediation analysis of perception toward entrepreneurship. Journal of Economics, Business and Management, 4(2). https://doi.org/10.7763/JOEBM.2016.V4.375 104

Kume A., Kume, V. and Shahini, B. (2013) Entrepreneurial characteristics amongst university Students in Albania. European Scientific Journal. 9(16) Issn: 1857-7881. http://eujournal.org/index.php/esj/article/viewFile/1144/1160. Accessed 6th May 2016. 
Machio, M. P. (2012). The effect of chronic illness on labour market outcomes in Kenya. Oxford: Centre for the study of African Economics.

Malebana, J. (2014). Entrepreneurial intentions and entrepreneurial motivation of South African Rural University students. Journal of Economics and Behavioral Studies, 6(9), 709-726 (ISSN: 2220-6140)18.

Nguyen, N. (2017). Entrepreneurial intention of international business students in Vietnam: a survey of the country joining the Trans-PacificPartnership. Journal of Innovation and Entrepreneurship, 6, 7. https://doi.org/10.1186/s13731017-0066-Z

Nonis, S. A., \& Hudson, G. I. (2006). Academic performance of college students: influence of time spent studying and working. Journal of Education for Business, 81(3), 151-159.

Olorundare, A.S. and Kayode, D.J. (2014). Entrepreneurship education in Nigerian universities: a tool for national transformation. Asia Pacific Journal of Educators and Education, Vol. 29, 155-175.

Peng, Z., Lu, G., \& Kang, H. (2012). Entrepreneurial intentions and its influencing factors: a survey of the university students in Xi'an China. Journal of Creative Education, 13, 95-99.

Per D. (1995) Determinants of entrepreneurial intentions. Paper prepared for the RENT IX Workshop, Piacenza, Italy, Nov. 23-24, https://eprints.qut.edu.au/2076/1/RENT_IX.pdf. Accessed 5th November, 2016.

Schultz, T. P., \& Tansel, A. (1997). Wage and labour supply effects of illness in Cote d'Ivoire and Ghana: instrumental variable estimates for days disabled. Journal of Development Economics, 53, 251-286.

Shapero, A., \& Sokol, L. (1982). The social dimensions of entrepreneurship. Encyclopedia of Entrepreneurship (pp. 72-90) Cliffs, NJ: Prentice-Hall ISBN 0132758261.

Tong X.A., Tong D.Y.K., and Loy L.C., (2011). Factors influencing entrepreneurial intention among university students. International Journal of Social Sciences and Humanity Studies. 3(1), ISSN: 1309-8063 (Online) 487.

University of Ibadan. (2015). Pocket Statistics. Ibadan: Academic Planning Unit, Office of the Vice Chancellor, Ibadan: University of Ibadan,

Urve V. Ene K. and Toomas, P. (2007). Students' attitudes and intentions toward entrepreneurship at Tallinn university of technology https://ideas.repec.org/p/ttu/wpaper/154.html. Accessed 10 $0^{\text {th }}$ May 2016.

Submit your manuscript to a SpringerOpen ${ }^{\circ}$ journal and benefit from:

- Convenient online submission

- Rigorous peer review

Open access: articles freely available online

- High visibility within the field

Retaining the copyright to your article

Submit your next manuscript at $>$ springeropen.com 